TRAMES, 2009, 13(63/58), 1, 83-91

\title{
TWO CASES OF MARGINALIZATION TOLD FROM THE WINGS: “AMY FOSTER” AND SWEPT FROM THE SEA
}

\author{
Nurten Birlik \\ Middle East Technical University, Ankara
}

\begin{abstract}
Conrad's "Amy Foster" and its film adaptation, Beeban Kidron's Swept from the $\mathrm{Sea}$, tell the story of a cross-cultural encounter in a closed ethnocentric community. Yanko, a young man from the East Carpathians, is supposed to reformulate a new identity at the intersection of his native discourse and the new dominant discourse in England. In both the original story and the film, Yanko fails to find such an intersection as this closed community defines its members against the background of their ethnic background, and grants recognition or denies it on this principle. The differences in the film adaptation add to the richness of the original story by digging up certain details from Amy's perspective. This paper aims to offer a contrastive analysis of their cases, not from the center, but from the edges: one from Yanko's and the other from Amy's wing against the backdrop of the shifting perspective in narration.
\end{abstract}

DOI: $10.3176 /$ tr.2009.1.05

Keywords: Swept from the Sea, "Amy Foster", ethnocentricism, Joseph Conrad, Beeban Kidron, film adaptation

\section{Introduction}

Conrad's "Amy Foster" and its film adaptation, Beeban Kidron's Swept from the Sea, tell the story of a cross-cultural encounter in a closed ethnocentric community. As a result of a shipwreck, Yanko, a young man from the East Carpathians, falls from his high expectations of a promised land to be found in America to an intensely tragic struggle in a dystopic social context in England where he is denied any kind of recognition. In order to exist in this new social environment Yanko is supposed to reformulate a new identity at the intersection of his native discourse and the new dominant discourse. In both the original story and the film, Yanko fails to find such an intersection as this closed community defines its members against the background of their ethnic background, and grants 
recognition or denies it on this principle. As a result he is ostracized and humiliated, and pushed to the margins of passivity and silence. The conflict between this castaway and the local community is rendered visible from the very beginning of both works; and the narration is charged with tension originating from this conflict. Yanko can survive in this hostile context with the help of an outcast, Amy Foster, who offers him bread, and, later, her companionship. The rest of the narration in both works is built on the troubled attempts of these two marginal characters to position themselves in the community and their failure to do so due to the strong resistance they encounter in this process. In both works the command of language is inherently bound up with a possible access to discourse; accordingly Amy never shows "a desire for conversation" and Yanko can "never fully inhabit the language" (Epstein 1991:228) with "his broken English that resembled curiously the speech of a young child" (AF 186).

Though the film hints provocatively at many parallelisms to Conrad's story, it seems erroneous to conclude that it is completely loyal to the story. There are strong reasons to believe that the film is, in many ways, a rewriting of the story with a shifting perspective. The cross-cultural encounter and a sense of dislocation still occupy the centerpiece of the narration, but the film version of the story is explicitly marked by shifting of the perspective from which the details are rendered. While Conrad's story gives expression to their predicament from Yanko's perspective, in the film this overemphasis on Yanko is balanced, to a large extent, as Amy, too, is given the chance to assert herself. Her isolation from the story is justified; thus, she is more 'normalized' in the film. This is done at the expense of some substantial changes in the original story as the film seeks to restore some fragments left undeveloped or in ambiguity in the first story. As a result, the film brings another dimension to the reading of Conrad's text and definitely enriches the polyphonic nature of it.

\section{Amy Foster}

To have a better insight into both Conrad's story and its film adaptation, highlighting the main story line with references to "Amy Foster" prepares a wider ground for us: In "Amy Foster" Dr. Kennedy, "an attentive philosophical observer of human nature", tells Yanko's story to the frame-narrator (Griem 1992:132). In his narration, from the early scenes onwards Yanko appears as a miserable creature who is just a voice "crying piercingly strange words in the night," "like a wild bird caught in a snare" in need of help. In his attempts to contact the local people, he is brutally refused. After being beaten on different occasions by villagers including the children and a woman, he is in the end bundled into a wood-lodge by Swift who "felt the dread of an inexplicable strangeness" (AF 192) and who thinks that "he had done his duty to his community by shutting up a wandering and probably dangerous maniac" (AF 193). Amy gives him a half loaf of white bread when "he was throwing himself violently about in the dark, rolling 
on some dirty sacks, and biting his fists with rage, cold, hunger, amazement, and despair" (AF 193) in the wood-lodge. This act of charity means physical survival for Yanko who "was brought back again within the pale of human relations with his new surroundings" (AF 196). But it bears wider implications for Amy: by offering bread to Yanko, Amy, who has a "dull face, red, not with a mantling blush, but as if her flat cheeks had been vigorously slapped" (AF 182) acquires the position of a 'gracious lady' in his eyes and is granted recognition by another person for the first time in her life. It is worth recalling here that, in the story, in the depiction of Amy, the idea of defected body as a somatic sign of a psychological abnormality is employed but, in the film, this idea is undermined by the beautiful face of Amy we see on the screen. For Yanko the only 'comprehensible face' among these 'hardhearted' people is that of Amy; the other people's faces are mysterious and closed, "as mute as the faces of the dead who are possessed of a knowledge beyond the comprehension of the living" (AF 199). Yanko is carried away from Swift's wood-lodge by Swaffer, who is fond of 'outlandish' things, to his farm and is allowed to work in return for food. It does not take long for Yanko to win the sympathy of this old man: he saves his granddaughter from drowning, and from then on, Yanko is allowed to eat in the kitchen and is paid regular wages, which implies elevation of his position in the eyes of these people.

Amy and Yanko are attracted to each other, as a result of which Yanko becomes "the weird Amy's lover for the Colebrook community" (Birlik 2002: 147) and Amy is called as "a shameless hussy." The text highlights that this relationship is also the beginning of an awakening for Amy:

Yes it was in her to become haunted and possessed by a face, by a presence, fatally, as though she had been a pagan worshipper of form under the joyous sky - and to be awakened at last from that mysterious forgetfulness of self, from that enchantment, from that transport, by a fear resembling the unaccountable terror of a brute... (AF 185).

In the story, after the birth of their son, Amy replaces Yanko with their baby, Little John (interestingly Yanko means John in Yanko's native tongue). Rejected by Amy he turns to his son: in his morbid loneliness he needs a companion and wants to teach his native language to his son so that "he could have a man to talk with in that language that to our ears sounded so disturbing, so passionate, and so bizarre" (AF 205). This is taken as a threat by Amy, as Hooper surmises, "by speaking to her child in a strange language, Yanko is, in Amy's eyes, trying to turn the child into a stranger, to replicate in the child his own alienness and difference" (1996:60). She snatches the child out of his arms as he was "crooning to it a song such as the mothers sing to babies in his mountains," thinking that he might do the baby some harm (AF 205). She also objects "to him praying aloud after by-and-by, as he used to do after his old father when he was a child- in his own country" (AF 205). Speaking in his tongue carried ontological implications for Yanko but Amy cannot understand this as she is different from Yanko in their marginal positions. Yanko was once part of a transindividual (cultural) realm which is alien to Amy. As Krajka puts 
it: Yanko's "emergence from the sea definitely is not one from zero degree of culture, from an embryo of humanity, to climb up the evolutionary tree" (1999:157), but, it is a 're-entry' for him; therefore, he needs others in his life.

However, it would not be far fetched to suggest that Amy gains some sort of access to the community after her marriage. As Kennedy says: "I had heard already of domestic differences. People were saying that Amy Foster was beginning to find out what sort of man she had married" (AF 205). In this remark there is the implication that Amy is much closer to the community than Yanko and gradually comes to share the community's view of Yanko. We can even go so far as to suggest that marriage and motherhood elevate Amy in the eyes of the community. Another way of looking at the issue might be that local people sympathize with her as they think that Amy is victimized in this marriage. Whatever the reason is, Amy is given some sort of recognition by them. However, we do not have the chance to learn the exact nature of Amy's feelings as she is never given the chance to voice them.

Feeling rejected, Yanko becomes pathetic and resumes his previous position of the helpless creature. He has high fever and in his delirium he retreats into his native tongue and his expressions become a closed book to Amy which she cannot decipher; and he fails in his attempts to communicate himself to her. She is afraid of his utterances which, ironically, were a demand for water: "Water! Give me water." In his misery "a gust of rage" comes over him. Amy leaves him in his sick bed with "the maternal instinct and that unaccountable fear" for her parent's house in case he might do some harm to the baby. This is the peak of misery for Yanko as it is depicted by Dr. Kennedy:

He was muddy. I covered him up and stood in silence, catching a painfully gasped word now and then. They were no longer in his own language. The fever had left him, taking with it the heat of life. And with his panting breast and lustruous eyes he reminded me again of a wild creature under the net; of a bird caught in a snare. She left him. She had left him - sick - helpless-thirsty (AF 208).

In the ending scene, Yanko cannot understand Amy's departure: “'Gone!' he said, distinctly. 'I had only asked for water - only for a little water", a few lines further he says: "Why' he cried, in the penetrating and indignant voice of a man calling to a responsible maker" (AF 208). Shortly after this utterance he dies without seeing Amy again.

Now Amy works for Swaffers, that is, she is positioned in a house which offers protection. When Kennedy sees Little John he cannot help seeing the father in the son with his big black eyes, "with his fluttered air of a bird in a snare." Looking at him, he seems "to see again the other one - the father, cast out mysteriously by the sea to perish in the supreme disaster of loneliness and despair" (AF 209).

\section{Swept from the Sea and the shifting perspective}

In the film, instead of the frame narrator, Dr. Kennedy (Ian McKellen) tells the story through flashbacks to Miss Swaffer (Kathy Bates). By way of comparison, his voice-over, even when he is off-camera, is far from detached as Yanko 
(Vincent Perez) seems to have replaced his son, who died at the typhus epidemic of 74. Very suitably, narration bears the imprints of this intimacy and, from the very outset, he is hostile to Amy (Rachel Weisz) and holds her responsible for Yanko's death. Paradoxically, however, his narration undermines itself and, somehow, we have more access to Amy's predicament; and Amy becomes a more central figure than Yanko in the film.

Unlike the original story, Yanko's background until he comes to Colebrook is given in much too general terms. From the very beginning in the film, Yanko's masculinity and ethnic origins are emphasized. His countrymen are given in their vitality despite their poverty, which is contrasted with his misery on the train to Hamburg. With the shipwreck he moves from one mode of discourse to another one: in a hostile environment where his reception is reduced to his ethnic and cultural roots, and "without the protection of linguistic and social familiarity" (Epstein 228), he commits himself to carving out a new life both for himself and Amy. Again, people insist on seeing him as 'alien' and can tolerate his existence only when he is out of their sight. This closed community's cruelty to outsiders is explicitly articulated in a series of concentrated sequences at the beginning of the film: one of these sequences concerns an old woman who comes in agony to the shore after hearing the shipwreck, but immediately after she learns it is not one of their ships, she says: "Praises be to God". This reaction foreshadows what kind of treatment Yanko will receive there.

Unlike the story, Amy's is the first face Yanko sees in this alien land. She stares at Yanko's face entranced while Mrs. Swift takes him as a beast. Afterwards, Amy saves him from the attacking dog but cannot stop Mr. Swift from giving him a heavy blow. She gives bread and a blanket to him and washes his bleeding face and feet. However, his hunger and misery are not emphasized in fact, he is more confident and can challenge, if necessary, other members of the community; and his suppressed anger in Amy Foster is more explicitly articulated in the film. Later he is taken away by Swaffer for whom Yanko is a 'funniosity'.

Amy is a simpleton or, at her best, a 'mystery' to the villagers. This idea is solidified by her strange relationship to nature. Rain and the sea seem to provide a source of vitality, a sort of orgasmic relief for her: in one extraordinary trance-like scene, for example, she is depicted as trying to catch her breath in the rain. In the tableau-like scenes, the idea of paganness in Amy, which is vaguely hinted in the original story, is further developed in the film. Precisely these scenes where Amy's corporal image merges into a pagan worshipper of the sea suspend the flow of events to give us a privileged vantage point from which we have an insight into real nature of Amy. Anything that is beautiful in her life comes from the sea, including her son and husband, which implies a non-symbolic value in Lacanian sense of the term to her: "The ancient sea. The dark sea...That's where all the heart of the earth have been lost, to love and to fear lie waiting to be reborn." Yanko is aware of the bizarre nature of this perception and aptly says: "This is not Christian". All these implications are crystallized in one of the strongly charged shots in which Amy collects 'gifts' from the sea and stores them in her cave, 
which is a kind of temple for her. The visual excess of the images in this particular scene implies that this is more than just an idyllic perception of nature: she deifies the sea and what it offers her. When her cave catches fire (obviously due to two of her father's friends), she says to Yanko: "They've taken my home" to which Yanko replies: "Whatever they do to us, whatever they take from us, I'm your home and you're mine." It is hardly surprising that we see them making love in their nuptial night in a little pond in her cave, which seems to be a kind of paganistic blessing of their marriage.

Amy's isolation is fuelled to a large extent by her familial background. Her own family poses a threat to her rather than offers her a site of comfort, protection and recognition. Being misfits, her parents, too, exist in turmoil and cannot set a good example for Amy on her way to integration to the culture she lives in. She is a 'bloody embarrassment' as her father calls her, or a 'disgrace' as the voice-over says because, "She was the product of a family scandal that impoverished her parents." Her father calls her as the 'queer sort' and the mother's reply is: "Is it any wonder? The way you treat her would silence the birds in the blessed trees", and Amy hears their remarks. In another scene when Yanko addresses Amy as "A gracious lady, great [sic] beautiful," Isaac Foster is astonished and says: "Our Amy? You'd have as much chance with Swaffer's mare. And a better time of it, too. I shouldn't wonder." Later on he insults her in front of Yanko, who screams at him in protest. Isaac Foster's hostility to Amy (and partly Amy's choice for being a misfit) is clarified in a later scene when her mother reveals that Isaac is, in fact, her brother. She was carrying her before Isaac laid hands on her. Then her mother retorts: "Bad you were conceived and bad you've remained." She has always been 'bad' in the eyes of her parents since the beginning, which might have pushed her away both from them and the community at large.

It should come as no surprise, then, that she does not care about them and their questions fall on deaf ears. She falls into silence which becomes a kind of confinement from which nobody can retrieve her. It is a site of existence, for her, a site of total renunciation of the community and all that it stands for. Therefore, it is definitely not a submissive silence as in Kennedy's words: "She used silence as a weapon against them." Thus, she falls back on her own resources to be able to withstand the humiliation she encounters. In such a context, to Yanko's remark; "Their eyes are like glass," Amy replies with an exasperated matter-of-factness: "I don't care to understand them ... I eat with them, I work with them. But I do not live with them. I don't need to understand them". In another line of interpretation, she problematizes the line between language and silence; submission and protest; and action and passivity.

One of the central arguments running through the film is that Amy's estrangement from the community is her choice, not an imposition on her. She chooses deliberately and consciously to position herself on the margin of her culture. A powerful rejoinder to this argument is that when she went to the parish school she did not make any attempt to learn how to read or write. Kennedy could not see a reason for her retardation: "I presumed she was slow of mind," next week she 
began to read and write perfectly adequately. She kept it for some months and then stopped. There is little doubt that Dr. Kennedy failed to diagnose her real problem, a failure which he repeats in seeing what Yanko means for Amy.

In the film, their alienation seems to be solidified after the marriage and after the birth of their son. Even when they assume traditional roles (husband/wife, or father/mother) which, under normal conditions, make an access into the community easier, they cannot leave their previous image as misfits behind. Her parents withdraw all resources and contact, and the rest of the community, too, maintains their hostility. In one charged scene, for example, Amy is humiliated by the village boys: "It's a bastard, that baby... It's got a tail, that baby ... She is a witch! Gypsy." This is the ultimate expression of their cruelty.

It is worthwhile to note that in the original story it is Yanko who drives the boy into alienation while, in the film, it is Amy, who poses such a threat. Yanko has friends to stand by him (Kennedy and Swaffers) unlike poor unlovable Amy. However, there is a gradual disengagement of Yanko not only from the community (with which he already had weak ties) but also from Kennedy after the marriage. He seems to realize that the roles and positions granted by the dominant discourse are not accessible to them, and that they can never break out of the confinement of their marginalized position. He could tolerate this before marriage and the birth of their son, but the previous symmetries in his life have been shattered. Now Yanko has to speak both for himself and Amy, and later for the boy, as in his own words: "For me I accept, I am strong. But for Amy and our baby, I do not accept". When Kennedy advises him to go away he says: "Amy now is home. And she is here but my boy will leave when he is a man". He envisions a totally different life for his son.

Interestingly, Amy becomes sensitive to the assaults of the village people now, but, unlike the story, the film emphasizes that she is not estranged from Yanko due to this hostility. This is conveyed through the visual details, like her bringing the cradle closer to Yanko when he is in his sickbed, or her whispering compassionate words in Yanko's ears. The symbiotic tie between them is once more articulated in the ending scene where Yanko says: "I would change nothing, my love, my gold". Then comes the final remark from him which makes the shifting of perspective in the film most explicit: "We are the lucky ones." Unlike the story in which the community appears as the triumphant side in this struggle, they feel superior to the community members in the film.

Why Yanko says they are 'the lucky ones' demands attention. In fact, this is not the first time he says this: the audience hear it before during their nuptial night in the cave. With these words he seems to imply that they are superior to others whom he sees as shallow identities. They were denied recognition in their community but had access to something else: intersubjectivity and a potential to love, or to something else which is alien even to the audience. This might have a direct bearing on Yanko's persistent use of the word 'home' in different scenes: the others were locked in the prison house of their 'self' but they found their 'home' in each other. A straight explanation is secreted so deeply into their 
intersubjective realm that the statement: "We are the lucky ones", resists a simplistic approach but it leaves its imprint on the memory of the audience.

Just after Yanko dies, Kennedy asks Amy, with an accusing tone of voice, why she left him. His words fall on deaf ears as she retreats into silence again. Kennedy says: "She did not take care of him" to Miss Swaffer, who strongly disagrees: "Yanko suffered all these things because he found his home in the heart of Amy Foster as she found her home in his." Then she raises a rather challenging question which causes Kennedy to revise his reaction and which makes him apologize to Amy for his misconduct: "Did your love blind you to hers?" This scene bears wider implications for Amy, too. After Kennedy asks for forgiveness she says: "Who will forgive me?". Her question is significant as it is an attempt to articulate her feelings and thus, an attempt to bridge the gap between herself and the community.

As can be seen, the differences in the film adaptation add to the richness of the original story by digging up certain details from Amy's perspective. Still, the central messages in the original story remain the same as both works engage us in an ongoing inner monologue with ourselves about the perception of one's identity and to what extent the recognition granted to that identity can determine one's life. Both works emphasize the idea that in a closed community individuals of another ethnic origin are brutally disenfranchised from the mainstream communal life and are pushed to the margins of silence and passivity. As a result, both works manage to give us a thorough understanding of their case, not from the center, but from the edges: one from Yanko's and the other from Amy's wing.

\author{
Address: \\ Nurten Birlik \\ Department of Foreign Language Education \\ Faculty of Education \\ Middle East Technical University \\ 06531 Balgat Ankara \\ Turkey \\ Tel.: 903122106492 \\ E-mail: nbirlik@metu.edu.tr,nbirlik@eircom.net
}

\title{
References
}

Birlik, Nurten ( 2002 ) "Subversion of the Oedipus: the marriage of two castaways in 'Amy Foster"'. In Joseph Conrad and his work, 142-152. Nesrin Eruysal, ed. Ankara: Department of Foreign Language Education, METU.

Conrad, Joseph (1991) “Amy Foster". In The complete fiction of Joseph Conrad. Vol. I, 181-209. Samuel Hynes, ed. New York: The Ecco Pres.

Epstein, Hugh (1991) "'Where he is not wanted': impression and articulation in 'The Idiots' and 'Amy Foster'”. Conradiana 23:3, 221-232.

Griem, Eberhard (1992) "Physiological Possibility in Joseph Conrad's 'Amy Foster': the problem of narrative technique". Conradiana 24, 2, 126-134. 
Hooper, Myrtle (1996) “'Oh, I hope he won't talk': narrative and silence in 'Amy Foster”. The Conradian 21, 2, 51-64.

Krajka, Wieslaw (1999) "The multiple identities of Yanko Gooral". In Joseph Conrad: East European, Polish and worldwide, 131-163. Wieslaw Krajka, ed. (Conrad: Eastern and Western Perspectives, 8.) Boulder: East European Monographs; Lublin: Marie CurieSklodowska University Press; New York: Columbia University Press.

\section{Filmography}

Swept from the Sea (1997, dir. Beeban Kidron) 